\title{
A systematic review of associations between environmental factors, energy and fat intakes among adults: is there evidence for environments that encourage obesogenic dietary intakes?
}

\author{
Katrina Giskes ${ }^{1,2, *}$, Carlijn BM Kamphuis ${ }^{2}$, Frank J van Lenthe ${ }^{2}$, Stef Kremers ${ }^{3}$, \\ Mariel Droomers ${ }^{4}$ and Johannes Brug ${ }^{2}$ \\ ${ }^{1}$ School of Public Health and Institute of Health and Biomedical Innovation, Queensland University of Technology, \\ Brisbane, Australia: '2Department of Public Health, Erasmus Medical Center, PO Box 2040, 3000 CA Rotterdam, The \\ Netherlands: ${ }^{3}$ Department of Health Education and Health Promotion, Faculty of Health Sciences, University of \\ Maastricht, Maastricht, The Netherlands: ${ }^{4}$ Centre for Prevention and Health Services Research, National Institute for \\ Public Health and the Environment (RIVM), Bilthoven, The Netherlands
}

Submitted 22 March 2006: Accepted 14 November 2006: First published online 22 February 2007

\begin{abstract}
Objective: To review the literature examining associations between environmental factors, energy and fat intakes among adults, and to identify issues for future research. Methods: Literature searches of studies published between 1980 and 2004 were conducted in major databases (i.e. PubMed, Human Nutrition, Web of Science, PsychInfo, Sociofile). Additional articles were located by citation tracking. Results: Twenty-one articles met the inclusion criteria. No study provided a clear conceptualisation of how environmental factors may influence these dietary intakes. Availability, social, cultural and material aspects of the environment were relatively understudied compared with other factors such as seasonal/day of the week variation and work-related factors. Few studies examined the specific environmental factors implicated in the obesity epidemic, and there was little study replication. All studies were observational and cross-sectional.

Conclusions: It is too premature to conclude whether or not environmental factors play a role in obesogenic and unhealthy dietary intakes. More studies need to examine associations with those environmental factors thought to contribute to obesogenic environments. There needs to be more development in theories that conceptualise the relationship between environmental factors and dietary intakes.
\end{abstract}

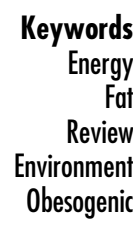

Unhealthy dietary intakes are risk factors for cardiovascular diseases and some forms of cancer $^{1}$, which are the most common causes of mortality in Western countries ${ }^{2,3}$. High levels of energy intake play a role by contributing to overweight and obesity ${ }^{4,5}$. Total fat and saturated fat intakes supply energy which contributes to overweight and obesity, and saturated fat influences blood levels of harmful (low-density lipoprotein) cholesterol $^{1}$. In an effort to achieve reductions in morbidity and mortality, dietary guidelines have been developed that endorse a suitable energy intake and promote low consumption levels of total and saturated fats ${ }^{5,6}$.

Until recently, the mainstream thought was that most determinants of dietary intakes occurred within the individual. Taste preferences, habit, nutrition knowledge, intentions, attitudes, outcome expectancies, self-efficacy and a number of other individual-level factors were considered primarily to drive what people eat ${ }^{7,8}$. However, these determinants were found to explain only a small portion of the variance in dietary intakes?
Recently, there has been a growing interest in the role of the environment in influencing people's dietary behaviour. This social ecological view of health emphasises that characteristics of the environment influence their health behaviours.

The rising prevalence of overweight and obesity is one of the major public health concerns today. Changes in dietary and physical activity behaviours are thought to underlie this trend. The determinants of these changes are their ecological paradigm for understanding obesity ${ }^{11}$ and argued that an increasingly 'obesogenic environment' contributed to the trends, there has been great popularity in examining whether environmental factors are associated with obesity-related behaviours.

A number of position papers and narrative reviews have identified environmental factors associated with the obesity epidemic $^{12,13}$; however no systematic review has examined the role of environmental factors in dietary individuals interact with their environments ${ }^{10}$ and that less well known. Since Swinburn and Egger introduced 
intakes. For example, the increasing densities of fast-food restaurants and convenience stores are thought to promote unhealthy food choices ${ }^{14}$. Media marketing of high-fat foods, their low prices and the greater range of convenience foods available are considered to be contributing factors ${ }^{11,14}$. The increased participation of women in the workforce has resulted in a greater reliance on convenience foods and less structured meal patterns, contributing to less healthy dietary intakes ${ }^{15}$. The greater variety of foods available in supermarkets may contribute to populations deviating from their traditional diets, adopting less healthy intakes, and portion sizes have increased $^{15}$. The presumed importance of these environmental determinants of unhealthy dietary behaviours have resulted in strong appeals for a better understanding of the role of environmental factors in dietary intakes and environmental interventions.

We conducted a systematic review of studies on environmental factors associated with energy, total and saturated fat intakes to summarise the current scientific evidence. We aimed to address which environmental factors have been examined in relation to these dietary outcomes to date, and identify issues for future research.

\section{Methods}

For the purposes of this study, the environment was defined as everything outside the individual ${ }^{16}$. A framework used in previous research ${ }^{17}$ that identifies four categories of environmental factors related to health behaviours was used to classify different environmental factors during the review process. The framework shares common features with ecological models ${ }^{18,19}$, stressing the importance of multiple types of environmental influences. The four categories that form this framework are:

1. Accessibility and availability. Including physical and financial accessibility of products and shops that are needed for an (un)healthy diet (e.g. access to shops, and availability of high-fat foods and less healthy snacks).

2. Social conditions. These arise from inter-personal interactions and include social relationships (e.g. family/marital status), social support and psychosocial stressors such as relationship difficulties.

3. Cultural conditions. These are the result of nonpersonal interactions or engagement with a larger group of people, such as culture-specific eating patterns, health value orientations, food experiences in childhood and cultural participation.

4. Material conditions. These include the financial situation (e.g. household income), material and social deprivation, and unfavourable working, housing and neighbourhood conditions (e.g. neighbourhood deprivation). These may affect behaviour through one of the previous environmental factors. For instance, a person's budgetary situation may partly determine their access to products and facilities. Living or working in an unfavourable environment might induce stress, which may relate to indifference concerning a healthy diet.

\section{Search strategy}

The current study was conducted within a larger study reviewing the literature of environmental factors associated with energy, fat, fruit and vegetable consumption among adults. Therefore, literature searches were conducted for a broader range of outcomes than those presented here, and included keywords for fruits and vegetables. Results on environmental factors associated with fruit and vegetable intakes can be found elsewhere ${ }^{20}$.

A review protocol based on guidelines from the Cochrane Reviewer's Handbook ${ }^{21}$ was used. Studies conducted among human subjects between 1 January 1980 and 31 December 2004 were located by searches of several major databases (i.e. PubMed, Human Nutrition, Web of Science, PsychInfo and Sociofile).

Broad search terms were used in the database searches to ensure that all potentially relevant articles entered the screening process. Each database was searched using database-specific indexing terms; suitable terms were selected from lists of the database indexing system. For databases that did not have their own indexing terms (i.e. Human Nutrition and Sociofile), we searched for keywords in titles. The sensitivity of searches was tested by seeing whether they located several key articles. Searches located 20653 potentially relevant titles (7440 in PubMed, 8325 in Human Nutrition, 4828 in Web of Science, 58 in PsychInfo and two in Sociofile). Detailed search strategies for each database can be found at http://mgzlx4. erasmusmc.nl/pwp/?ckamphuis.

\section{Inclusion criteria}

To be included, studies must have been published in English and conducted among a population-based sample of adults (i.e. studies examining disease or patient subgroups, and those conducted among participants below 18 years or above 60 years of age were excluded) and they must have quantified dietary intakes. In addition to this, studies must have been conducted in an established market economy as defined by the World Bank $^{22}$, and the dependent variable(s) must have been energy intake, total/saturated fat intakes or fruit and vegetable intakes. Intervention studies and studies with a research design that made it impossible to decipher associations between environmental factors and the outcome behaviours were excluded.

\section{Title scanning}

The title screening process was performed by two reviewers (K.G. and C.K.) and took place in three steps. 
First, the titles located from the search results were scanned, to exclude those outside the scope of the current study. Then the abstracts of all titles were examined by the reviewers. At this step, each reviewer produced a list of suitable articles. These lists were then combined, and both reviewers examined the pooled list independently. They read all study abstracts in the pooled list, and each produced a 'short list' of suitable articles. Discrepancies between reviewers in the 'short lists' were discussed, and a consensus was reached on whether or not the article(s) in question would be incorporated. A total of 55 articles were identified for inclusion at this stage. The reference lists of these articles were scanned and the selection of studies from the reference lists followed the same procedure outlined above. Another 12 publications extracted from reference lists were included in the review.

\section{Data extraction and summarisation}

The reviewers extracted data from half of the studies each. The study's details (i.e. the environmental factor(s) and dietary outcome(s) examined, whether environmental factors were objectively measured or self-reported, sample size, response rate, factors adjusted for in the analyses and the associations found) were summarised in data extraction tables.

In studies where sufficient data were available, effect sizes (ES) were calculated to interpret the magnitude of association of the environmental factors and make comparisons between studies. The formulae of Cohen ${ }^{23}$ were applied, adjusting for sample size. The magnitude of the ES were also interpreted according to the guidelines of Cohen, with cut-off points of $0.2-0.5$ for small ES, $0.5-0.8$ for moderate ES and $>0.8$ for large ES.

\section{Results}

Twenty-seven of the 67 studies selected for detailed review were excluded because they were design/theoretical papers or only mentioned environmental factors in their Discussion sections. Nineteen articles were excluded because they did not examine energy, total fat or saturated fat intakes; therefore, 21 articles remained in the current review. Table 1 summarises the country where the study was conducted, the environmental factor(s) examined and their measurement. Most studies examined more than one dietary outcome, and were conducted in the USA ( $n=11), \mathrm{UK} /$ Europe $(n=6)$ or Canada/Australia/Israel $(n=4)$. Just less than half of the studies $(n=9)$ measured the environmental factors objectively. All studies were cross-sectional. Only one study used multilevel analyses ${ }^{24}$; census block districts were the area level used in these analyses. All remaining studies were individual-level analyses.

The studies examined 81 associations between intakes and environmental factors, of which 41 were significant. Table 2 briefly summarises the associations found between environmental factors and each of the dietary intakes. This table shows that associations between environmental factors and intakes have been examined mostly for total fat consumption (39 associations were tested) compared with energy and saturated fat consumptions (22 and 20 associations were tested, respectively). Relatively few associations tested the potential influence of cultural factors on dietary intakes. There was little replication of studies testing the same hypotheses; often two associations were tested in different samples (e.g. men and women) from the same study.

Tables 3-5 detail the study characteristics and findings for each dietary outcome more extensively. For brevity, the following sections only describe findings for environmental factors for which two or more associations were tested.

\section{Associations between environmental factors and energy intakes}

Table 3 details the characteristics and findings of studies examining associations between environmental factors and energy intakes. Fourteen of the 22 associations examined in these studies demonstrated a significant relationship between the environmental factor and energy intakes.

No studies looked at associations between availability factors (such as types of stores available and what they stocked) and energy intakes. The influence of social factors (i.e. being married, having children or living with others) on energy intakes was examined in a number of studies. Living with others demonstrated large associations with energy intakes that differed in direction for men and women ${ }^{29}$. One study found that men living alone had lower energy intakes than those living with others; however, lower energy intakes were found among women that lived with others. The same study found that marital status was strongly associated with energy intakes; intakes were higher among married participants compared with their single counterparts ${ }^{29}$.

Only one study examined associations between cultural factors (the presence of others during mealtimes) and energy intakes, while a number of studies looked at material factors. Urban/rural residence demonstrated a large association with energy intakes; men and women living in rural areas had greater energy intakes than those in urban areas ${ }^{29}$. In a study that contrasted the energy intakes of men and women living in areas with different socio-economic characteristics, no differences were found ${ }^{40}$.

Other potential determinants of energy intakes that were examined in other studies were portion size, weekday/seasonal variations in intakes, and associations between workload and energy intakes. Two studies demonstrated strong direct effects between portion sizes and energy intakes ${ }^{38,39}$. Seasonal variations in intakes were measured in countries differing considerably in their 
Table 1 Details of included studies

\begin{tabular}{|c|c|c|c|c|}
\hline First author (year) & Dietary outcomes examined & Country & Environmental factor(s) & $\begin{array}{c}\text { Was environmental factor } \\
\text { subjectively or objectively measured? }\end{array}$ \\
\hline Cheadle $(1991)^{25}$ & Total fat & USA & Shelf space occupied by healthy foods in stores & Objective \\
\hline De Castro $(1992)^{26}$ & Energy, total fat & USA & Number of people present during meal & Subjective \\
\hline De Craene $(1990)^{27}$ & Total fat & Belgium & Location of residence, marital status & Subjective (both) \\
\hline Diehr $(1993)^{28}$ & Total fat & USA & $\begin{array}{l}\text { Percentage of the community not reaching } \\
\text { recommended intakes }\end{array}$ & Subjective \\
\hline Diez-Roux (1999) ${ }^{24}$ & Saturated fat & USA & Median income of neighbourhood, household income & Subjective (both) \\
\hline Friel $(2003)^{29}$ & Energy, total fat, saturated fat & Ireland & $\begin{array}{l}\text { Urban/rural residence, marital status, living situation } \\
\text { (alone/with others) }\end{array}$ & Subjective (all) \\
\hline Gibney $(1993)^{30}$ & Energy, total fat & Ireland & Family circumstances (married, children) & Subjective \\
\hline Haines $(2003)^{31}$ & Energy, total fat & USA & Weekend/weekday, season & Subjective \\
\hline Hellerstedt $(1997)^{32}$ & Total fat & USA & Psychological demands, job latitude, job strain & Subjective \\
\hline Johansson $(1999)^{33}$ & Total fat & Norway & Location of residence, household income & Objective (both) \\
\hline McCann $(1990)^{34}$ & Energy, total fat, saturated fat & USA & Period of high/low workload & Objective \\
\hline Morland (2002) ${ }^{35}$ & Total fat, saturated fat & USA & $\begin{array}{l}\text { Whether or not there were the following food stores } \\
\text { in the residential area: } \\
\text { - Supermarkets } \\
\text { - Grocery stores } \\
\text { - Full service restaurants }\end{array}$ & Objective (all) \\
\hline Pomerleau $(1997)^{36}$ & Total fat & Canada & Household income, source of income & Subjective (both) \\
\hline Raynor (2004)37 & Total fat & USA & Availability of high-fat foods at home & Subjective \\
\hline Rolls $(2002)^{38}$ & Energy & USA & Portion size & Objective \\
\hline Rolls $(2004)^{39}$ & Energy & USA & Portion size & Objective \\
\hline Rutishauser (1994) ${ }^{40}$ & Energy, total fat, saturated fat & Australia & Residing in a low or high socio-economic area & Objective \\
\hline Shahar $(2001)^{41}$ & Energy, total fat, saturated fat & Israel & Season (summer/winter) & Objective \\
\hline Subar $(1994)^{42}$ & Energy, total fat & USA & Season: summer or winter & Objective \\
\hline Tarasuk (1999)43 & Energy, total fat & Canada & Household food insecurity & Subjective \\
\hline Van Staveren $(1996)^{44}$ & Energy, total fat, saturated fat & The Netherlands & Season: summer or winter & Objective \\
\hline Wardle $(2000)^{45}$ & Energy & UK & Period of high/low workload & Objective \\
\hline
\end{tabular}


Table 2 Summary of associations found in the reviewed articles

\begin{tabular}{|c|c|c|c|}
\hline \multirow[b]{2}{*}{ Environmental factors } & \multicolumn{3}{|c|}{ Dietary intakes } \\
\hline & Energy & Total fat & Saturated fat \\
\hline \multicolumn{4}{|l|}{ Availability } \\
\hline High-fat food stocked in stores & & +1 & \\
\hline High-fat foods available at home & & +1 & \\
\hline Grocery store in the residential area & & 1 & +1 \\
\hline Supermarket in the residential area & & 1 & 1 \\
\hline Full service restaurant in the residential area & & 1 & 1 \\
\hline Fast-food restaurant in the residential area & & 1 & 1 \\
\hline \multicolumn{4}{|l|}{ Social factors } \\
\hline Being married & +2 & $+2 / 2$ & -2 \\
\hline Having children & 1 & 1 & \\
\hline Living with others & $+1 /-1$ & +2 & +2 \\
\hline \multicolumn{4}{|l|}{ Cultural factors } \\
\hline $\begin{array}{l}\text { Presence of others during mealtimes } \\
\text { Percentage of the community exhibiting high fat intakes }\end{array}$ & +1 & $\begin{array}{l}+1 \\
+1\end{array}$ & \\
\hline \multicolumn{4}{|l|}{ Material factors } \\
\hline Living in a rural area (compared with an urban area) & +2 & $+2 / 2$ & +2 \\
\hline Living in a disadvantaged area & 2 & 2 & $4 /-2$ \\
\hline Household income & & 3 & \\
\hline Household food insecurity & -1 & 1 & \\
\hline \multicolumn{4}{|l|}{ Other factors } \\
\hline Portion size & +2 & & \\
\hline Weekend (compared with weekdays) & +1 & +1 & \\
\hline Winter (compared with summer) & $+1 / 2 / 3$ & $+2 / 1$ & $+1 / 1$ \\
\hline Workload & +2 & $+1 / 1$ & $+1 / 1$ \\
\hline Work-related psychological demands & & $+1 / 1$ & \\
\hline Job strain & & $+1 / 1$ & \\
\hline Job latitude & & & \\
\hline Living in a northern region (in Belgium) & & +2 & \\
\hline
\end{tabular}

The numbers of significant effects found for the combination determinant-dietary outcome are given in bold; numbers not in bold are the number of non-significant effects found for the combination determinant-dietary outcome, or for which information on significance was not available.

+ indicates a positive association between environmental determinant and dietary outcome.

- indicates a negative association between environmental determinant and dietary outcome.

climate (USA, Israel and Europe), and mixed associations were seen ${ }^{31,41,42,44}$. Two studies found small differences in mean energy intakes between winter and summer, one found that intakes were marginally lower in winter among men ${ }^{42}$ while another study among men found that energy intakes were slightly higher in winter ${ }^{41}$. A study among women found no seasonal variation in energy intakes ${ }^{44}$. Greater energy intakes have been associated with higher workload in two studies, but the magnitude of these effects was small ${ }^{34,45}$.

\section{Associations between environmental factors and total fat intakes}

Studies examining associations between environmental factors and total fat intakes are described in Table 4. Sixteen of the 39 associations tested reached statistical significance.

There were no associations between availability factors and total fat intake that were replicated. A number of studies examined potential social determinants of fat intakes. Marital status and living situation demonstrated large effects on fat intakes in an Irish study ${ }^{29}$ and showed that being married or living with others was associated with higher fat intakes compared with being single or living alone. However, a Belgian study found no association between marital status and fat intakes ${ }^{27}$.

There were no replicated associations tested for any cultural factors and total fat intake. However, a number of studies examined associations with material factors. A US study found that living in a rural area was associated with a higher fat intake, and the Es of this relationship was large $^{29}$. However, a Norwegian study found no significant urban/rural differences ${ }^{33}$. Fat intakes in relation to the socio-economic characteristics of the residential area were examined in one study, but no significant association was found $^{40}$. Two studies examined the economic circumstances of households in relation to fat intakes, and took a number of confounding factors into account, but found that household income was not associated with fat intakes ${ }^{33,36}$

The majority of studies examined associations with other factors. There were mixed findings about seasonal variations in fat intake. Two small studies (one in Israel and one in Europe) demonstrated higher fat intakes in winter compared with summer ${ }^{41,44}$; however, a US study found very marginal differences in fat intakes between seasons ${ }^{42}$. Three studies examined associations between work conditions, such as psychological demands, job strain and workload, and fat intakes ${ }^{32,34,45}$. One study 
Table 3 Results of studies examining environmental factors associated with energy intakes

\begin{tabular}{|c|c|c|c|c|c|c|}
\hline First author (year) & $\begin{array}{l}\text { Sample size } \\
\text { (response rate \%) }\end{array}$ & Environmental factor(s) & Findings & $\begin{array}{l}\text { Was association } \\
\text { significant? }\end{array}$ & Magnitude of effect size & Adjusted for \\
\hline $\begin{array}{l}\text { De Castro } \\
(1992)^{26}\end{array}$ & $153(\mathrm{~N} / \mathrm{A})$ & $\begin{array}{l}\text { No. of people present during } \\
\text { meal }\end{array}$ & $\begin{array}{l}\text { Intake increased by } 22.50 \mathrm{kcal} \text { per person } \\
\text { present }\end{array}$ & Y & Unable to calculate & Nil \\
\hline Friel $(2003)^{29}$ & $6539(63)$ & $\begin{array}{l}\text { Marital status, urban/rural } \\
\text { residence, living } \\
\text { situation (alone/with } \\
\text { others) }\end{array}$ & $\begin{array}{l}\text { Single men consumed } 0.26 \mathrm{MJ} \text { day }{ }^{-1} \text { less } \\
\text { than married men, those living in rural areas } \\
\text { consumed } 0.03 \mathrm{MJ}^{-1} \mathrm{y}^{-1} \text { more than those } \\
\text { in urban areas and those living alone } \\
\text { consumed } 1.2 \mathrm{MJ} \text { day }{ }^{-1} \text { less than men } \\
\text { living with others } \\
\text { Single women consumed } 0.15 \mathrm{MJ} \mathrm{day}^{-1} \text { less } \\
\text { than their married counterparts, women in } \\
\text { rural areas consumed } 0.19 \mathrm{MJ} \text { day }{ }^{-1} \text { more } \\
\text { than those in urban areas and women living } \\
\text { alone consumed } 0.51 \mathrm{MJ} \text { day }^{-1} \text { more than } \\
\text { women living with others }\end{array}$ & $\begin{array}{l}\text { Men } \\
\text { - Marital status: } Y \\
\text { - Urban/rural: } Y \\
\text { Wiving situation: } Y \\
\text { Women } \\
\text { - Marital status: } Y \\
\text { - Urban/rural: } Y \\
\text { - Living situation: } Y\end{array}$ & $\begin{array}{l}\text { Men } \\
\text { - Marital status: large } \\
\text { - largan/rural residence: } \\
\text { - Living situation: large } \\
\text { Women } \\
\text { - Marital status: large } \\
\text { - Urban/rural residence: } \\
\text { large } \\
\text { - Living situation: large }\end{array}$ & $\begin{array}{l}\text { Age, gender, education, } \\
\text { occupation, medical card } \\
\text { eligibility, marital status, } \\
\text { location of residence, no. } \\
\text { in household }\end{array}$ \\
\hline Gibney $(1993)^{30}$ & $\begin{array}{l}87 \text { women } \\
\text { only (94) }\end{array}$ & $\begin{array}{l}\text { Family circumstances } \\
\text { (married, children) }\end{array}$ & $\begin{array}{l}\text { Single mothers consumed } 0.3 \mathrm{MJ} \text { day }^{-1} \text { less } \\
\text { than mothers with } 1-2 \text { children }\end{array}$ & $\mathrm{N} / \mathrm{A}$ & Unable to calculate & Nil \\
\hline Haines $(2003)^{31}$ & $990(\mathrm{~N} / \mathrm{A})$ & $\begin{array}{l}\text { Weekend/weekday and } \\
\text { season }\end{array}$ & $\begin{array}{l}\text { Intakes } 82 \mathrm{kcal} \mathrm{day}^{-1} \text { higher on weekends } \\
\text { and } 23 \mathrm{kcal} \mathrm{day}^{-1} \text { higher in winter }\end{array}$ & $\begin{array}{l}\text { - Day of week: } Y \\
\text { - Season: } Y\end{array}$ & Unable to calculate & $\begin{array}{l}\text { Age, gender, ethnicity, } \\
\text { income, region, urban/rural } \\
\text { residence, household size, } \\
\text { receipt of social security/ } \\
\text { food assistance }\end{array}$ \\
\hline McCann $(1990)^{34}$ & $10(\mathrm{~N} / \mathrm{A})$ & Workload & $\begin{array}{l}\text { During periods of high workload participants } \\
\text { consumed } 240 \mathrm{kcal}^{\text {day }}{ }^{-1} \text { more vs. low } \\
\text { workload periods }\end{array}$ & Y & Small effect & Nil \\
\hline $\begin{array}{l}\text { Rutishauser } \\
(1994)^{40}\end{array}$ & $225(57-77)$ & $\begin{array}{l}\text { Residing in low or high } \\
\text { socio-economic area }\end{array}$ & $\begin{array}{l}\text { Men and women living in disadvantaged } \\
\text { areas consumed respectively } 0.5 \text { and } \\
0.4 \mathrm{MJ}_{\text {day }}{ }^{-1} \text { less energy than those in } \\
\text { advantaged areas }\end{array}$ & $\begin{array}{l}\text { NS for men } \\
\text { and women }\end{array}$ & Small & Nil \\
\hline Shahar $(2001)^{41}$ & $\begin{array}{l}94 \text { men } \\
\text { only }(\mathrm{N} / \mathrm{A})\end{array}$ & Season (summer/winter) & $\begin{array}{l}\text { In winter, men consumed } 158 \mathrm{kcal}_{\text {day }}^{-1} \text { more } \\
\text { than in summer }\end{array}$ & NS & No effect & Nil \\
\hline Subar $(1994)^{42}$ & 20143 & Season (summer/winter) & $\begin{array}{l}\text { In winter, men consumed } 39 \mathrm{kcal} \mathrm{day}^{-1} \text { less than } \\
\text { in the summer; in winter, women consumed } \\
14 \mathrm{kcal} \mathrm{day}^{-1} \text { more than in the summer }\end{array}$ & N/A & Unable to calculate & $\begin{array}{l}\text { Age, race, region, } \\
\text { education, poverty index }\end{array}$ \\
\hline Tarasuk $(1999)^{43}$ & $\begin{array}{l}145 \text { women } \\
\text { only }(68.3)\end{array}$ & Household food insecurity & $\begin{array}{l}\text { Women in households with high food insecurity } \\
\text { consumed } 1058 \mathrm{~kJ}^{-1} \text { day }{ }^{-1} \text { less than those with } \\
\text { low food insecurity }\end{array}$ & Y & Unable to calculate & $\begin{array}{l}\text { Disposable income, } \\
\text { presence of employment } \\
\text { income, presence of } \\
\text { partner in the household, } \\
\text { women's level of } \\
\text { education, smoking status, } \\
\text { ethnic identity }\end{array}$ \\
\hline $\begin{array}{l}\text { Van Staveren } \\
(1996)^{44}\end{array}$ & $\begin{array}{l}114 \text { women } \\
\text { only (N/A) }\end{array}$ & Season: summer or winter & $\begin{array}{l}\text { No difference in energy intakes between } \\
\text { summer and winter }\end{array}$ & NS & No effect & Day of week \\
\hline Wardle $(2000)^{45}$ & $90(N / A)$ & Workload & $\begin{array}{l}\text { During high workload period, energy intakes } \\
\text { were } 109 \mathrm{kcal}^{-1} \mathrm{day}^{-1} \text { higher than during low } \\
\text { workload period }\end{array}$ & Y & Small effect & Nil \\
\hline
\end{tabular}

N/A - not available; $Y$ - effect was statistically significant $(P \leq 0.05)$; NS - effect was not significant. 
Table 4 Results of studies examining environmental factors associated with total fat intakes

\begin{tabular}{|c|c|c|c|c|c|c|}
\hline First author (year) & $\begin{array}{l}\text { Sample size } \\
\text { (response rate \%) }\end{array}$ & Environmental factor(s) & Findings & $\begin{array}{l}\text { Was association } \\
\text { significant? }\end{array}$ & Magnitude of effect size & Adjusted for \\
\hline Cheadle $(1991)^{25}$ & $5654(53.4)$ & $\begin{array}{l}\text { Shelf space occupied by } \\
\text { healthy foods in stores }\end{array}$ & $\begin{array}{l}\text { Correlation coefficient between store } \\
\text { healthfulness scale and \% energy } \\
\text { from fat: }-0.52\end{array}$ & Y & Small to moderate effect & Nil \\
\hline De Castro $(1992)^{26}$ & $153(\mathrm{~N} / \mathrm{A})$ & $\begin{array}{l}\text { No. of people present } \\
\text { during meal }\end{array}$ & $\begin{array}{l}\text { Regression slope for no. of people present: } \\
8.45 \mathrm{kcal} \text { from fat per person present }\end{array}$ & Y & Unable to calculate & Nil \\
\hline De Craene $(1990)^{27}$ & $1609(75)$ & $\begin{array}{l}\text { Marital status, location } \\
\text { of residence }\end{array}$ & $\begin{array}{l}\text { Single men had fat consumption score } 10 \\
\text { points lower (healthier) than married men; } \\
\text { single women had fat consumption score } \\
5 \text { points higher (less healthy) than married } \\
\text { women } \\
\text { Men and women living in the northern } \\
\text { region had higher fat consumption score (less } \\
\text { healthy) than those in the southern region } \\
\text { ( } 13 \text { and } 16 \text { points for men and women, } \\
\text { respectively) }\end{array}$ & $\begin{array}{l}\text { Marital status } \\
\text { - Men: NS } \\
\text { - Women: NS } \\
\text { Region } \\
\text { - Men: Y } \\
\text { - Women: Y }\end{array}$ & $\begin{array}{l}\text { Unable to calculate } \\
\text { for marital status and } \\
\text { region of residence }\end{array}$ & Age, gender \\
\hline Diehr $(1993)^{28}$ & $335(\mathrm{~N} / \mathrm{A})$ & $\begin{array}{l}\% \text { of community not } \\
\text { reaching recommended } \\
\text { intakes }\end{array}$ & $\begin{array}{l}\text { When added to model to explain fat consumption, } \\
\% \text { of community exhibiting high fat intakes } \\
\text { explained } 1.4 \% \text { of total variance }\end{array}$ & Y & Small & Nil \\
\hline
\end{tabular}

$\begin{array}{lll}\text { Friel }(2003)^{29} & 6539(62) & \text { Marital status, living } \\ & \text { situation (alone/with } \\ & \text { others), urban/rural } \\ & \text { residence }\end{array}$

Gibney $(1993)^{30}$

Haines $(2003)^{31}$

Hellerstedt $(1997)^{32} \quad 3843$ (range $50-93 \%$ by worksite)

87 women only (94) Family circumstances (married, children)

$9900(\mathrm{~N} / \mathrm{A})$

Weekend/weekday

Psychological demands in job, job latitude and job strain
Single men consumed $0.3 \%$ less energy from fat than married men, men in rural areas consumed $0.7 \%$ more energy from fat than urban men, and men living alone consumed $0.2 \%$ less energy from fat than men living with others

Single women consumed $1.8 \%$ less energy from fat than married women, women in rura areas consumed $0.5 \%$ more energy from fat than urban women, and women living alone consumed $0.6 \%$ less energy from fat than women living with others

Single mothers consumed $5.4 \%$ less energy as fat than mothers with 1-2 children

$0.7 \%$ higher energy from fat on weekends

Men with high psychological demands in their job consumed $51 \mathrm{kcal} \mathrm{day}^{-1}$ more than men with low psychological demands; women with high psychological demands consumed $4 \mathrm{kcal}_{\text {day }}{ }^{-1}$ less

Men and women with low job latitude consumed respectively 14 and $3 \mathrm{kcal}$ day $^{-1}$ less than their counterparts with high job latitude

Men with high job strain consumed

$22 \mathrm{kcal} \mathrm{kay}^{-1}$ more and women with

high job strain consumed $3 \mathrm{kcal}$

day ${ }^{-1}$ less than those with low job strain
Marital status: $Y$

- Urban/rural: Y

- Living situation: $Y$

- Marital status: large - Urban/rural residence: large

mard eligibility, marital status,

- Living situation: large

Women

Women

- Marital status: $Y$ - Marital status: large

- Urban/rural:Y - Urban/rural residence:

- Living situation: $Y$ large

- Living situation: large

N/A

Unable to calculate

Nil

Unable to calculate

Age, gender, ethnicity, energy intake, income, region, urban/rural residence, household size, receipt of social security/food assistance

Psychological demands Unable to calculate

- Men:Y

- Women: NS

demands

Gender, age, marita

status, race, time

employed, hours worked

per week, job category,

salary, environmen
physical hazards,

Job latitude

- Men: NS

Unable to calculate

for job latitude

education

No effect for job strain for

- Men: Y

- Women: NS 


\begin{tabular}{|c|c|c|c|c|c|c|}
\hline First author (year) & $\begin{array}{c}\text { Sample size } \\
\text { (response rate \%) }\end{array}$ & Environmental factor(s) & Findings & $\begin{array}{l}\text { Was association } \\
\text { significant? }\end{array}$ & Magnitude of effect size & Adjusted for \\
\hline \multirow[t]{2}{*}{ Johansson $(1999)^{33}$} & $3144(63)$ & $\begin{array}{l}\text { Household income, } \\
\text { location of residence }\end{array}$ & $\begin{array}{l}\text { No difference in fat intakes between income } \\
\text { groups for men and women }\end{array}$ & $\begin{array}{l}\text { Income and place of } \\
\text { residence NS for men } \\
\text { and women }\end{array}$ & $\begin{array}{l}\text { Income and place } \\
\text { of residence no effect for } \\
\text { men and women }\end{array}$ & Age, gender, education \\
\hline & & & $\begin{array}{l}\text { Rural men and women derived } 1 \% \text { more } \\
\text { of their energy intakes from fat vs. } \\
\text { counterparts living in cities }\end{array}$ & & & \\
\hline McCann $(1990)^{34}$ & $10(\mathrm{~N} / \mathrm{A})$ & Workload & $\begin{array}{l}\text { During periods of high workload participants } \\
\text { consumed } 5 \% \text { more energy from fat than in } \\
\text { periods of low workload }\end{array}$ & $\mathrm{Y}$ & Moderate & Nil \\
\hline Morland (2002) ${ }^{35}$ & $10623(\mathrm{~N} / \mathrm{A})$ & $\begin{array}{l}\text { Types of food stores } \\
\text { in residential area }\end{array}$ & $\begin{array}{l}\text { Likelihood of low fat consumption with } \\
\text { following stores in the residential area } \\
\text { - Supermarkets: } 1.09(1.01,1.18) \\
\text { - Grocery stores: } 0.97(0.90,1.04) \\
\text { - Full service restaurants: } 0.95(0.87,1.05) \\
\text { - Fast-food restaurants: } 0.99(0.91,1.08)\end{array}$ & All outlets: NS & No effect for all outlets & $\begin{array}{l}\text { Education, income and } \\
\text { other types of food stores }\end{array}$ \\
\hline Pomerleau $(1997)^{36}$ & $43099(77-97)$ & Household income & $\begin{array}{l}\text { Likelihood of low fat intake among those } \\
\text { with low household income: } 0.95(0.75,1.19)\end{array}$ & NS & No effect & $\begin{array}{l}\text { Gender, age and marital status, } \\
\text { other socio-economic variables }\end{array}$ \\
\hline Raynor $(2004)^{37}$ & $162(\mathrm{~N} / \mathrm{A})$ & $\begin{array}{l}\text { Availability of high-fat } \\
\text { foods at home }\end{array}$ & $\begin{array}{l}\% \text { of high-fat foods available at home } \\
\text { positively related to total fat intake: } r=0.25\end{array}$ & $\mathrm{Y}$ & Moderate & Nil \\
\hline Rutis-hauser (1994) ${ }^{40}$ & $225(57-77)$ & $\begin{array}{l}\text { Residing in low or high } \\
\text { socio-economic area }\end{array}$ & $\begin{array}{l}\text { Men and women in deprived areas } \\
\text { consumed respectively } 0.5 \text { and } 1.6 \mathrm{~g} \\
\text { day }^{-1} \text { more fat than those in advantaged areas }\end{array}$ & $\begin{array}{l}\text { NS for men } \\
\text { and women }\end{array}$ & $\begin{array}{l}\text { - Men: No } \\
\text { - Women: No }\end{array}$ & Nil \\
\hline Shahar $(2001)^{41}$ & 94 men only $(\mathrm{N} / \mathrm{A})$ & Season (summer/winter) & $\begin{array}{l}\text { In winter, men consumed } 9 \mathrm{~g} \\
\text { day }^{-1} \text { more fat than in summer }\end{array}$ & $\mathrm{Y}$ & Moderate & Energy intake \\
\hline Subar $(1994)^{42}$ & 20143 & Season (summer/winter) & $\begin{array}{l}\text { In winter, men consumed } 1.1 \mathrm{~g} \text { day }^{-1} \text { less } \\
\text { than in the summer; in winter, women } \\
\text { consumed } 0.1 \mathrm{~g}^{-1} y^{-1} \text { less than in summer }\end{array}$ & $\mathrm{N} / \mathrm{A}$ & Unable to calculate & $\begin{array}{l}\text { Age, race, region, } \\
\text { education, poverty index }\end{array}$ \\
\hline Tarasuk (1999) ${ }^{43}$ & $\begin{array}{l}145 \text { women } \\
\text { only }(68.3)\end{array}$ & Household food insecurity & $\begin{array}{l}\text { Women in households with high food } \\
\text { insecurity consumed } 8.45 \mathrm{~g}^{-1} \mathrm{day}^{-1} \text { less fat } \\
\text { than those in households with low } \\
\text { food insecurity }\end{array}$ & NS & Unable to calculate & $\begin{array}{l}\text { Disposable income, presence } \\
\text { of employment income, presence of } \\
\text { partner in household, women's } \\
\text { level of education, smoking } \\
\text { status, ethnic identity }\end{array}$ \\
\hline Van Staveren $(1996)^{44}$ & $\begin{array}{l}114 \text { women } \\
\text { only }(\mathrm{N} / \mathrm{A})\end{array}$ & Season: summer or winter & $\begin{array}{l}\text { Fat contributed } 2.2 \% \text { more to total energy } \\
\text { intake in winter vs. summer }\end{array}$ & $\mathrm{Y}$ & Unable to calculate & $\begin{array}{l}\text { Adjustment for time of the } \\
\text { week: weekends, Friday, } \\
\text { Monday-Thursday }\end{array}$ \\
\hline Wardle $(2000)^{45}$ & $90(\mathrm{~N} / \mathrm{A})$ & Workload & $\begin{array}{l}\text { During period of high workload, total } \\
\text { fat contributed } 1 \% \text { less to total energy } \\
\text { intake vs. low workload periods }\end{array}$ & NS & No effect & Nil \\
\hline
\end{tabular}

N/A - not available; $Y$ - effect was statistically significant $(P \leq 0.05)$; NS - effect was not significant. 
found no association between psychological demands and job strain and women's fat intakes, whereas men with high psychological demands and high job strain consumed more fat than their counterparts with low psychological demands and low job strain ${ }^{32}$. A small study showed a positive relationship of moderate magnitude between workload and fat intakes ${ }^{34}$, whereas another study found no association between work stress and fat intakes ${ }^{45}$. Location of residence also showed a relationship with fat intakes in a Belgian study, which illustrated significant regional differences in fat consumption ${ }^{27}$.

\section{Associations between environmental factors and saturated fat intakes}

Studies examining associations between environmental factors and saturated fat intakes are shown in Table 5 . Nine of the 20 associations tested were statistically significant.

Similar to the situation reported for energy and total fat intakes, no associations with availability factors were replicated. Studies that examined potential social determinants found that single adults had moderately higher saturated fat intakes than their married counterparts, and that these differences were large ${ }^{29}$. The same study found a large positive association between saturated fat intake and living alone; participants that lived alone had higher intakes compared with those living with others ${ }^{29}$.

No studies examined associations between saturated fat intakes and cultural factors; however, a number looked at the potential influence of material factors. Living in an urban area was associated with higher intakes in one study $^{29}$, and the differences in intakes between urban and rural areas were large in magnitude. The influence of living in a deprived neighbourhood was examined in two studies $^{24,40}$; both found no significant differences in saturated fat consumption between people residing in socio-economically contrasting areas. A US study found that household income was positively related to saturated fat intakes among men and women ${ }^{24}$.

A number of other studies looked at the potential influence of other factors on saturated fat intakes. A study among men in Israel showed that saturated fat intakes were moderately higher in winter compared with summer ${ }^{41}$. However, no significant seasonal differences in saturated fat intakes were seen among women in The Netherlands ${ }^{44}$. Of two studies examining the influence of working conditions, one showed that workers consumed slightly (but significantly) more saturated fat during periods of high workload ${ }^{34}$, but the other found that intakes were not different during periods of high work stress ${ }^{45}$.

\section{Discussion}

We performed a systematic review of the literature examining associations between environmental factors and energy, total and saturated fat intakes. Potentially relevant environmental factors from social-ecological models for health behaviours (such as availability, social, cultural and material conditions) were relatively understudied in relation to these specific dietary outcomes - research has predominantly focused on other environmental influences (i.e. season/day of the week variation, work-related factors). Few studies have examined the specific environmental factors that have been implicated in the obesity epidemic, such as fastfood/convenience stores, marketing of unhealthy foods and larger portion sizes. Therefore, it is too premature to conclude that the environment does or does not play an important role in unhealthy dietary behaviour among the adult population at the current time.

Both the public and health professionals have a great deal of interest in the presumed impact of the food environment on weight gain and health. However, our systematic review indicates that these notions are currently not well supported by scientific evidence. The evidence base in this area still needs to grow before extensive investment in developing environmental interventions to bring about dietary change can be justified. How can we tackle this?

First, there is a need for more theoretical growth in this area before our knowledge can be advanced by further research. Research on environmental factors associated with dietary intakes needs to develop beyond the phase of merely reporting associations between environmental factors and dietary intakes. The relationship between the environment and how it influences food choice needs to be conceptualised. There needs to be some more empirical thought given to which environmental factors are most likely to be related to dietary intakes, i.e. are they accessibility and availability issues, social factors, cultural conditions and/or material factors? There needs to be some consideration given to the pathways/mechanisms by which environmental factors are likely to influence intakes. Most studies included in the review examined associations between environmental factors and dietary intakes without stating clear hypotheses regarding the underlying mechanisms. Being aware of the mechanisms by which environmental factors influence dietary intakes is necessary so that the research can be translated into effective interventions among the population. For example, does the actual environment influence people's behaviour, or are people's perceptions of the environment a stronger influence? Another question is whether the environment operates directly on dietary behaviour, or whether its influence is mediated through other environmental-level factors (e.g. urbanisation or area deprivation) or individual-level factors (e.g. self-efficacy or nutrition knowledge). Existing conceptual models are of some assistance, but these are still in their formative stages. Some ecological theories of health behaviour may also offer some direction; however, they are also limited as they list and categorise potential environmental factors but do 
Table 5 Results of studies examining environmental factors associated with saturated fat intakes

\begin{tabular}{|c|c|c|c|c|c|c|}
\hline First author (year) & $\begin{array}{l}\text { Sample size } \\
\text { (response rate \%) }\end{array}$ & Environmental factor(s) & Findings & $\begin{array}{l}\text { Was association } \\
\text { significant? }\end{array}$ & Magnitude of effect size & Adjusted for \\
\hline Diez-Roux $(1999)^{24}$ & $13095(N / A)$ & $\begin{array}{l}\text { Median income of } \\
\text { neighbourhood, } \\
\text { household income }\end{array}$ & $\begin{array}{l}\text { Men in poorest neighbourhoods consumed } 0.3 \mathrm{~g} \\
\text { day }^{-1} \text { less saturated fat than those in advantaged } \\
\text { areas, whereas women in disadvantaged areas } \\
\text { consumed } 0.4 \mathrm{~g} \mathrm{day}^{-1} \text { more } \\
\text { Men and women in the poorest households } \\
\text { consumed respectively } 0.5 \text { and } 0.9 \mathrm{~g} \mathrm{day}^{-1} \\
\text { less saturated fat than the wealthiest group }\end{array}$ & $\begin{array}{l}\text { Neighbourhood differences } \\
\text { men and women: NS } \\
\text { Household income men } \\
\text { and women: } Y\end{array}$ & Unable to calculate & $\begin{array}{l}\text { Age, gender, race, } \\
\text { energy intake, field } \\
\text { centre, individual-level } \\
\text { income }\end{array}$ \\
\hline Friel $(2003)^{29}$ & $6539(62)$ & $\begin{array}{l}\text { Marital status, living } \\
\text { situation (alone/with } \\
\text { others), urban/rural } \\
\text { residence }\end{array}$ & $\begin{array}{l}\text { Single men consumed } 0.1 \% \text { more energy } \\
\text { from saturated fat than married men, those } \\
\text { living in rural vs. urban areas consumed } 0.4 \% \\
\text { more energy from saturated fat, and those living } \\
\text { alone consumed } 0.2 \% \text { less saturated fat vs. men } \\
\text { living with others } \\
\text { Single women consumed } 0.1 \% \text { more energy from } \\
\text { saturated fat than married women, those living } \\
\text { in rural vs. urban areas consumed } 0.4 \% \text { more } \\
\text { energy from saturated fat, and women living } \\
\text { alone consumed } 0.2 \% \text { energy from saturated fat } \\
\text { less than women living with others }\end{array}$ & $\begin{array}{l}\text { Men } \\
\text { - Marital status: } Y \\
\text { - Urban/rural: } Y \\
\text { Living situation: } Y \\
\text { Women } \\
\text { - Marital status: } Y \\
\text { - Urban/rural: } Y \\
\text { - Living situation: } Y\end{array}$ & $\begin{array}{l}\text { Men } \\
\text { - Marital status: moderate } \\
\text { largan/rural residence: } \\
\text { - Living situation: large } \\
\text { Women } \\
\text { - Marital status: moderate } \\
\text { - Urban/rural residence: } \\
\text { large } \\
\text { - Living situation: large }\end{array}$ & $\begin{array}{l}\text { Age, gender, education, } \\
\text { occupation, medical } \\
\text { card eligibility, marital } \\
\text { status, location of } \\
\text { residence, no. in } \\
\text { household }\end{array}$ \\
\hline McCann $(1990)^{34}$ & $10(\mathrm{~N} / \mathrm{A})$ & Workload & $\begin{array}{l}\text { During periods of high workload participants } \\
\text { consumed } 3 \% \text { more energy from saturated } \\
\text { fat than periods of low workload }\end{array}$ & Y & Small & Nil \\
\hline Morland (2002) ${ }^{35}$ & $10623(N / A)$ & $\begin{array}{l}\text { Types of food stores in } \\
\text { residential area }\end{array}$ & $\begin{array}{l}\text { Likelihood of low saturated fat consumption } \\
\text { with the following outlets in the residential area } \\
\text { - Supermarkets: } 1.09(0.99,1.20) \\
\text { - Grocery stores: } 0.92(0.84,1.00) \\
\text { - Full service restaurants: } 1.03(0.91,1.15) \\
\text { - Fast-food restaurants: } 0.95(0.86,1.05)\end{array}$ & $\begin{array}{l}\text { NS for all stores except for } \\
\text { grocery stores }\end{array}$ & $\begin{array}{l}\text { No effect for all stores except } \\
\text { for grocery stores which had } \\
\text { a small effect }\end{array}$ & $\begin{array}{l}\text { Education, income and } \\
\text { other types of food } \\
\text { stores }\end{array}$ \\
\hline $\begin{array}{l}\text { Rutishauser } \\
(1994)^{40}\end{array}$ & $225(57-77)$ & $\begin{array}{l}\text { Residing in low or high } \\
\text { socio-economic area }\end{array}$ & $\begin{array}{l}\text { Men and women living in deprived areas } \\
\text { consumed respectively } 1.4 \text { and } 1.3 \mathrm{~g} \\
\text { day }^{-1} \text { more saturated fat than those in } \\
\text { advantaged areas }\end{array}$ & NS for men and women & Unable to calculate & Nil \\
\hline Shahar $(2001)^{41}$ & $\begin{array}{l}94 \text { men } \\
\text { only }(N / A)\end{array}$ & Season (summer/winter) & $\begin{array}{l}\text { In winter men consumed } 3 \mathrm{~g}_{\text {day }}{ }^{-1} \text { more saturated } \\
\text { fat than in summer }\end{array}$ & Y & Moderate & Energy intake \\
\hline $\begin{array}{l}\text { Van Staveren } \\
(1996)^{44}\end{array}$ & $\begin{array}{l}114 \text { women } \\
\text { only (N/A) }\end{array}$ & $\begin{array}{l}\text { Season: summer } \\
\text { or winter }\end{array}$ & $\begin{array}{l}\text { Saturated fat contributed } 0.7 \% \text { more to energy } \\
\text { intake in winter vs. summer }\end{array}$ & NS & Unable to calculate & $\begin{array}{l}\text { Adjustment for time } \\
\text { of the week: weekends, } \\
\text { Friday, Monday- } \\
\text { Thursday }\end{array}$ \\
\hline Wardle $(2000)^{45}$ & $90(\mathrm{~N} / \mathrm{A})$ & Workload & $\begin{array}{l}\text { During periods of high workload, saturated fat } \\
\text { contributed } 0.45 \% \text { more to energy intake than } \\
\text { in low workload periods }\end{array}$ & NS & No effect & Nil \\
\hline
\end{tabular}


not specify how they influence behaviour ${ }^{46}$. Further development of this theory is necessary to facilitate the formation of recommendations for health practitioners and for deriving hypotheses to be tested in subsequent research. We should also take advantage of knowledge from other fields of research such as sociology, urban geography and economy, as these fields know much about the consequences of physical and/or social deterioration in neighbourhoods. Fields such as economics have a stronger knowledge about the effects of advertising and the way people spend their money. Crossfertilisation of knowledge from different fields may be the key to growth in this area.

Furthermore, the influence of the environment needs to be examined in relation to other 'traditional' (i.e. individual-level) determinants of dietary behaviour ${ }^{47}$. No known study has simultaneously looked at the relative influence of (and interaction between) environmental and individual-level factors on dietary behaviour. Examining the relative influence of factors at different levels is an important step to help determine where research to understand how dietary behaviour, and interventions and resources to bring about behaviour change, could be best targeted.

Stronger study designs will also help to unravel the relationship between the environment and dietary behaviour. All the studies in the current review were observational and examined cross-sectional associations between environmental factors and dietary intakes. These study designs provide an indication of significant associations, but are limited for examining causal relationships between the factors of interest and dietary intakes $^{48}$. Longitudinal and experimental study designs would enable environmental determinants (rather than correlates) of dietary behaviour to be identified. The use of 'natural experiments' (e.g. examining intakes of residents before and after the opening of a takeaway food store, or making cross-country comparisons to examine the influence of cultural factors) may offer opportunities to examine the influence of environmental factors that are difficult to manipulate ${ }^{49}$.

Our search strategy only located studies that were published in peer-reviewed journals and referenced in electronic databases; therefore, they may be influenced by publication bias. We tried to minimise this by also performing searches in smaller and more specialised databases. The studies included in the review tested 81 associations, of which 41 were found to be significant, suggesting that publication bias may have played a role in the current study with an over-representation of studies showing significant effects. Other limitations that may have influenced the study findings were differences in the conceptualisation, measurement and summary of the environmental determinants and/or dietary intakes in the different studies. Even though strict inclusion criteria were used, environmental or dietary intake measurements sometimes differed markedly between studies, and may have contributed to variation in the associations found.

The findings of this review suggest that there is currently insufficient evidence to conclude that environmental factors do or do not influence obesogenic or unhealthy dietary behaviours. Further research needs to examine the environmental factors that the current literature implicates as part of an obesogenic environment, as we found few studies that examined these factors. The evidence base in this area still needs to grow in the ways mentioned above, before practice recommendations can be made or extensive investment in developing environmental interventions to bring about dietary change can be justified. Examination of environmental factors associated with dietary habits preceding energy and fat intakes (such as food choice and habits) may help to unravel further whether the environment influences health outcomes through dietary behaviour. Additionally, study replication is necessary to confirm or disprove the findings of previous studies.

\section{Acknowledgements}

Sources of funding: K.G. is supported by an Australian National Health and Medical Research Council (NHMRC) Sidney Sax International Post Doctoral Fellowship (grant identification number: 290540). The project was funded by the Netherlands Organisation for Health Research and Development. K.G. conceptualized and wrote the manuscript.

\section{Conflict of interest declaration: None.}

Authorship responsibilities: K.G. and C.K. searched for and synthesised the manuscripts. The remaining coauthors offered valuable input and feedback on the manuscript.

Acknowledgements: The authors wish to thank Gert-Jan de Bruijn for his useful comments on an earlier draft of the manuscript.

\section{References}

1 World Health Organization (WHO). Diet, Nutrition and the Prevention of Chronic Diseases. Report of a WHO Study Group. WHO Technical Report Series No. 797. Geneva: WHO, 1990.

2 Murray C, Lopez A. Mortality by cause for eight regions of the world: Global Burden of Disease Study. Lancet 1997; 349: 1269-76.

3 Michaud C, Murray C, Bloom B. Burden of disease implications for future research. Journal of the American Medical Association 2001; 285: 535-9.

4 Hu F, Manson J, MJ S, Colditz G, Liu S, Solomon C, et al. Diet, lifestyle and risk of type 2 diabetes mellitus among women. New England Journal of Medicine 2001; 345: 790-7.

5 McCullough M, Feskanich D, Rimm E, Giovannucci E, Ascherio A, Variyam J, et al. Adherence to the Dietary Guidelines for Americans and risk of major chronic disease in men. American Journal of Clinical Nutrition 2000; 72: $1223-31$. 
6 McCullough M, Feskanich D, Stampfer M, Rosner B, Hu F, Hunter D, et al. Adherence to the Dietary Guidelines for Americans and risk of major chronic disease among women. American Journal of Clinical Nutrition 2000; 72: 1214-22.

7 Armitage CJ, Conner M. Social cognition models and health behaviour: a structured review. Psychology \& Health 2000; 15: $173-89$

8 Glanz K, Lewis FM, Rimer BK, eds. Health Behavior and Health Education: Theory, Research and Practice, 2nd ed. San Francisco, CA: Jossey-Bass Publishers, 1997.

9 Glanz K, Kristal AR, Tilley BC, Hirst K. Psychosocial correlates of healthful diets among male auto workers. Cancer Epidemiology, Biomarkers \& Prevention 1998; 7: 119-26.

10 Giles-Corti B, Donovan R. Socioeconomic status differences in recreational physical activity levels and real and perceived access to a supportive physical environment. Preventive Medicine 2002; 35: 601-11.

11 Swinburn B, Egger G, Raza F. Dissecting obesogenic environments: the development of a framework for identifying and prioritizing environmental interventions for obesity. Preventive Medicine 1999; 29: 563-70.

12 Wansink B, Kim J. Bad popcorn in big buckets: portion size can influence intake as much as taste. Journal of Nutrition Education and Behavior 2005; 37: 242-5.

13 Pollard J, Greenwood D, Kirk S, Cade J. Lifestyle factors affecting fruit and vegetable consumption in the UK Women's Cohort Study. Appetite 2001; 37: 71-9.

14 Booth K, Pinkston M, Poston W. Obesity and the built environment. Journal of the American Dietetic Association 2005; 105: S110-7.

15 Banwell C, Hinde S, Dixon J, Sibthorpe B. Reflections on expert consensus: a case study of the social trends contributing to obesity. European Journal of Public Health 2005; 15: 564-8.

16 Sallis JF, Owen N. Ecological models of health behavior. In: Glanz K, Lewis FM, Rimer BK, eds. Health Behavior and Health Education. Theory, Research and Practice, 3rd ed. San Francisco, CA: Jossey-Bass, 2002; 462-84.

17 Kamphuis C, van Lenthe F, Giskes K, Brug J, Mackenbach J. Perceived environmental determinants of physical activity and fruit and vegetable consumption among low and high socioeconomic groups in the Netherlands. Health \& Place 2006 Jun 29; [Epub ahead of print].

18 Cohen D, Scribner RA, Farley T. A structural model of health behavior: a pragmatic approach to explain and influence health behaviors at the population level. Preventive Medicine 2000; 30: 146-54.

19 Hovell M, Wahlgren D, Gehrman C. The behavioral ecological model. In: DiClemente R, Crosby R, Kegler M, eds. Emerging Theories in Health Promotion Practice and Research. Strategies for Improving Public Health. San Francisco, CA: Jossey-Bass, 2002; 347-85.

20 Kamphuis CBM, Giskes K, Wendel-Vos W, de Bruijn GJ, Brug $J$, van Lenthe F. Environmental determinants of fruit and vegetable consumption - a systematic review. British Journal of Nutrition 2006; 96: 620-35.

21 Higgins J, Green S. Cochrane Handbook for Systematic Reviews of Interventions 4.2.5. Chichester: John Wiley \& Sons Ltd, 2005.

22 World Bank. World Bank Web Site [online], 2006. Available at www.worldbank.com

23 Mullen P, Simons-Morton D, Ramirez G, Frankowski R, Green L, Mains D. A meta-analysis of trials evaluating patient education and counseling for three groups of preventive health behaviours. Patient Education and Counseling 1991; 32: $157-73$.

24 Diez-Roux AV, Nieto FJ, Caulfield L, Tyroler HA, Watson RL, Szklo M. Neighbourhood differences in diet: the Athero- sclerosis Risk in Communities (ARIC) study. Journal of Epidemiology and Community Health 1999; 53: 55-63.

25 Cheadle A, Psaty BM, Curry S, Wagner E, Diehr P, Koepsell T, et al. Community-level comparisons between the grocery store environment and individual dietary practices. Preventive Medicine 1991; 20: 250-61.

26 de Castro JM, Brewer EM. The amount eaten in meals by humans is a power function of the number of people present. Physiology \& Behavior 1992; 51: 121-5.

27 De Craene I, De Backer G, Kornitzer M, De Henauw S, Bara $\mathrm{L}$, Rosseneu M, et al. Determinants of fat consumption in a general population. Revue d'Epidemiologie et de Sante Publique 1990; 38: 539-43.

28 Diehr P, Koepsell T, Cheadle A, Psaty BM, Wagner E, Curry S. Do communities differ in health behaviors? Journal of Clinical Epidemiology 1993; 46: 1141-9.

29 Friel S, Kelleher CC, Nolan G, Harrington J. Social diversity of Irish adults nutritional intake. European Journal of Clinical Nutrition 2003; 57: 865-75.

30 Gibney M, Lee P. Patterns of food and nutrient intake in a suburb of Dublin with chronically high unemployment. Journal of Human Nutrition and Dietetics 1993; 6: 13-22.

31 Haines PS, Hama MY, Guilkey DK, Popkin BM. Weekend eating in the United States is linked with greater energy, fat, and alcohol intake. Obesity Research 2003; 11: 945-9.

32 Hellerstedt WL, Jeffery RW. The association of job strain and health behaviours in men and women. International Journal of Epidemiology 1997; 26: 575-83.

33 Johansson L, Thelle DS, Solvoll K, Bjorneboe GE, Drevon CA. Healthy dietary habits in relation to social determinants and lifestyle factors. British Journal of Nutrition 1999; $\mathbf{8 1}$ : 211-20.

34 McCann B, Warnick G, Knopp R. Changes in plasms lipids and dietary intake accompanying shifts in perceived workload and stress. Psychosomatic Medicine 1990; 52: 97-108.

35 Morland K, Wing S, Diez Roux A. The contextual effect of the local food environment on residents' diets: the atherosclerosis risk in communities study. American Journal of Public Health 2002; 92: 1761-7.

36 Pomerleau J, Pederson LL, Ostbye T, Speechley M, Speechley KN. Health behaviours and socio-economic status in Ontario, Canada. European Journal of Epidemiology 1997; 13: 613-22

37 Raynor HA, Polley BA, Wing RR, Jeffery RW. Is dietary fat intake related to liking or household availability of high- and low-fat foods? Obesity Research 2004; 12: 816-23.

38 Rolls B, Morris E, Roe L. Portion size of food affects energy intake in normal-weight and overweight men and women. American Journal of Clinical Nutrition 2002; 76: 1207-13.

39 Rolls BJ, Roe LS, Kral TV, Meengs JS, Wall DE. Increasing the portion size of a packaged snack increases energy intake in men and women. Appetite 2004; 42: 63-9.

40 Rutishauser I, Wheeler C, Conn J, O'Dea K. Food and nutrient intake in a randomly-selected sample of adults: demographic and temporal influences on energy and nutrient intakes. Australian Journal of Nutrition and Dietetics 1994; 51: 157-66.

41 Shahar DR, Yerushalmi N, Lubin F, Froom P, Shahar A, Kristal-Boneh E. Seasonal variations in dietary intake affect the consistency of dietary assessment. European Journal of Epidemiology 2001; 17: 129-33.

42 Subar AF, Frey CM, Harlan LC, Kahle L. Differences in reported food frequency by season of questionnaire administration: the 1987 National Health Interview Survey. Epidemiology 1994; 5: 226-33.

43 Tarasuk VS, Beaton GH. Women's dietary intakes in the context of household food insecurity. Journal of Nutrition 1999; 129: 672-9. 
44 van Staveren W, Deurenburg P, Burema J, de Groot L, Hautvast J. Seasonal variation in food intake, pattern of physical activity and change in body weight in a group of young adult Dutch women consuming self-selected diets. International Journal of Obesity 1986; 10: 133-45.

45 Wardle J, Steptoe A, Oliver G, Lipsey Z. Stress, dietary restraint and food intake. Journal of Psychosomatic Research 2000; 48: 195-202.

46 Brug J, Oenema A, Ferreira I. Theory, evidence and intervention mapping to improve behaviour nutrition and physical activity measures. International Journal of Behavioral Nutrition and Physical Activity 2005; 4: 2.
47 Kremers S, Visscher T, Seidell J, van Mechelen W, Brug J. Cognitive determinants of energy balance-related behaviours: measurement issues. Sports Medicine 2005; 35: 923-33.

48 French SA, Story M, Jeffery RW. Environmental influences on eating and physical activity. Annual Review of Public Health 2001; 22: 309-35.

49 Petticrew M, Cummins S, Ferrell C, Findlay A, Higgins C, Hoy C, et al. Natural experiments: an underused tool in public health. Public Health 2005; 119: 751-7. 